\title{
Crystallization of ikaite and its pseudomorphic transformation into calcite: Raman spectroscopy evidence
}

Nuria Sánchez Pastor ${ }^{\mathrm{a} *}$, Markus Oehlerich ${ }^{\mathrm{b}}$, José Manuel Astilleros ${ }^{\mathrm{a}, \mathrm{c}}$, Melanie Kaliwoda $^{\mathrm{d}}$, Christoph C. Mayr ${ }^{\mathrm{b}, \mathrm{e}, \mathrm{f}}$, Lurdes Fernández-Díaz ${ }^{\mathrm{a}, \mathrm{c}}$ and Wolfgang W. Schmahl ${ }^{\text {b,d,e }}$

${ }^{a}$ Departamento de Cristalografía y Mineralogía, Universidad Complutense de Madrid, 28040, Madrid, Spain

${ }^{\mathrm{b}}$ Department für Geo- und Umweltwissenschaften, Ludwig-Maximilians Universität, 80333 München, Germany

${ }^{c}$ Instituto de Geociencias. (UCM-CSIC), 28040, Madrid, Spain

${ }^{\mathrm{d}}$ Mineralogische Staatssammlung München, 80333 München, Germany

${ }^{\mathrm{e}}$ Geo-Bio-Center, Ludwig-Maximilians Universität, 80333 München, Germany

${ }^{\mathrm{f}}$ Institut für Geographie, Friedrich-Alexander-Universität Erlangen-Nürnberg, 91058 Erlangen, Germany

\footnotetext{
* Corresponding Author Tel.: +34-913944881

E-mail address: nsanchez@ucm.es (N. Sánchez-Pastor)

Coauthors: m.oehlerich@1rz.uni-muenchen.de (M. Oehlerich); jmastill@ucm.es (J. M. Astilleros); melanie.kaliwoda@lrz.uni-muenchen.de (M. Kaliwoda); c.mayr@lrz.unimuenchen.de (C. Mayr); 1fdiaz@ucm.es (L. Fernández-Díaz); wolfgang.schmahl@1rz.unimuenchen.de (W. W. Schmahl).
} 


\section{Abstract}

Ikaite $\left(\mathrm{CaCO}_{3} \cdot 6 \mathrm{H}_{2} \mathrm{O}\right)$ is a metastable phase that crystallizes in nature from alkaline waters with high phosphate concentrations at temperatures close to $0^{\circ} \mathrm{C}$. This mineral transforms into anhydrous calcium carbonate polymorphs when temperatures rise or when exposed to atmospheric conditions. During the transformation in some cases the shape of the original ikaite crystal is preserved as a pseudomorph. Pseudomorphs after ikaite are considered as a valuable paleoclimatic indicator. In this work we conducted ikaite crystal growth experiments at near-freezing temperatures using the single diffusion silica gel technique, prepared with a natural aqueous solution from the polymictic lake Laguna Potrok Aike $\left(51^{\circ} 57^{\prime} \mathrm{S}, 70^{\circ} 23^{\prime} \mathrm{W}\right)$ in Patagonia, Argentina. The ikaite crystals were recovered from the gels and the transformation reactions were monitored by in situ Raman spectroscopy at two different temperatures. The first spectra collected showed the characteristic features of ikaite. In successive spectra new bands at 1072, 1081 and $1086 \mathrm{~cm}^{-1}$ and changes in the intensity of bands corresponding to the $\mathrm{OH}$ modes were observed. These changes in the Raman spectra were interpreted as corresponding to intermediate stages of the transformation of ikaite into calcite and/or vaterite. After a few hours, the characteristics of the Raman spectrum were consistent with those of calcite. While ikaite directly transforms into calcite at $10^{\circ} \mathrm{C}$ in contact with air, at $20^{\circ} \mathrm{C}$ this transformation involves the formation of intermediate, metastable vaterite. During the whole process the external shape of ikaite crystals was preserved. Therefore, this transformation showed the typical characteristics of a pseudomorphic mineral replacement, involving the generation of a large amount of porosity to account for the large difference in molar volumes between ikaite and calcite. A mechanism involving the coupled dissolution of ikaite and crystallization of calcite/vaterite is proposed for this replacement.

Keywords: Ikaite, Crystal Growth, Phosphate, Calcium Carbonate Polymorphs, Raman Spectroscopy, Replacement. 


\section{Introduction}

In addition to the anhydrous calcium carbonate $\left(\mathrm{CaCO}_{3}\right)$ minerals calcite, aragonite, and vaterite, there are two metastable hydrous $\mathrm{CaCO}_{3}$ phases, ikaite $\left(\mathrm{CaCO}_{3} \cdot 6 \mathrm{H}_{2} \mathrm{O}\right)$ and monohydrocalcite $\left(\mathrm{CaCO}_{3} \cdot \mathrm{H}_{2} \mathrm{O}\right)$. The latter two are relevant carbonate phases in sedimentary environments because of both their role as precursors to calcite (Clarkson et al., 1992) and their geochemical implications (De Lurio and Frakes, 1999). In spite of this relevance, these phases have garnered little attention. Although synthetic $\mathrm{CaCO}_{3} \cdot 6 \mathrm{H}_{2} \mathrm{O}$ was known from earlier laboratory studies (Pelouze, 1865), ikaite in nature was first observed quite recently (Pauly, 1963) at the bottom of Ikka Fjord in Greenland, where it precipitates due to mixing of cold $\left(3^{\circ} \mathrm{C}\right)$ carbonate-rich submarine springs with seawater. Subsequently, ikaite and its pseudomorphs were discovered in a variety of natural environments (Suess et al., 1982; Jansen et al., 1987; Bischoff et al., 1993a,b; Larsen, 1994; Ito, 1996, 1998; Omelon et al., 2001; Dieckmann et al., 2010; Lu et al., 2012; Last et al., 2013; Nomura et al., 2013).

Ikaite is metastable with respect to calcite at all temperatures and low pressure in the presence of liquid water. In contrast with calcite, aragonite and, vaterite, which become less soluble as temperature increases, the solubility of ikaite increases with increasing temperature and ikaite is the most soluble $\mathrm{CaCO}_{3}$ phase at any temperature above $0^{\circ} \mathrm{C}$ (Bischoff et al., 1993). All known occurrences of ikaite are limited to environments where temperatures are between -2 and $7^{\circ} \mathrm{C}$, and it readily transforms into calcite and/or vaterite at higher temperatures (Marland, 1975; Shaikh and Shearman, 1986; Gaines et al., 1997; Tang et al., 2009). Studies of the structure of synthetic ikaite in combination with the investigation of the geochemical characteristics of the micro-environments in which calcium carbonate precipitation occurs (Bischoff et al., 1993a; Ito, 1998) have provided a fundamental framework for defining the limits to ikaite occurrence in nature. The crystallization of metastable ikaite previously has been related to specific physicochemical conditions like high alkalinity and elevated phosphate concentrations (Bischoff et al., 1993a).

It is well known (Rickaby et al., 2006) that ikaite captures and preserves, as hydrated water within its crystal structure, the $\delta^{18} \mathrm{O}$ value of the water in which it formed with an isotope fractionation factor of $1.0029( \pm 0.0002)$. The potential for the hydration waters 
of marine ikaite to record the Pleistocene evolution of $\delta^{18} \mathrm{O}$ was confirmed by Rickaby and co-workers (Rickaby et al., 2006). However, in the case of warming of the depositional environment or exposure to atmospheric conditions, natural ikaite samples disintegrate, within minutes to hours, into a mush of water and small whitish crystals of calcite and/or vaterite. Sometimes this conversion results in the generation of calcitic aggregates whose external shape perfectly reproduces the habit of the original ikaite crystals. These pseudomorphs are commonly referred to as glendonites, which are typically found in cold-water deposits from Late Precambrian to the Pleistocene. Because ikaite crystals record the oxygen isotope composition of the aqueous solution from which they form during their growth, as mentioned before, the occurrence of calcite pseudomorphs after ikaite are potentially valuable as a quantitative paleoclimatological indicator (Schrag and DePaolo., 1993; Larsen, 1994; De Lurio and Frakes, 1999; Swainson and Hammond, 2001; Adkins et al., 2002; Rickaby et al., 2006; Lu et al., 2012; Oehlerich et al., 2013). However, the reliability of geochemical data derived from these pseudomorphs depends on the extent of alteration during the transformation of ikaite into calcite, which can greatly vary depending on the mechanism operating during this transformation (Lu et al., 2012). The oxygen isotope fractionation factor between lake water and calcite transformed from ikaite was found to be 1.0324 at Laguna Potrok Aike (Argentina). This value is close to that found for calcite directly precipitated in the water column in isotopic equilibrium (Oehlerich et al., 2013). However, there are very few reports about the transformation process of ikaite into anhydrous calcium carbonate phases like calcite and/or vaterite.

The goal of our study is to understand the processes undergone by ikaite crystals in contact with the laboratory air atmosphere at temperatures above $4^{\circ} \mathrm{C}$ and the mechanisms that control these processes. As a first step to achieve this goal, we conducted crystal growth experiments to obtain ikaite crystals using the singlediffusion-silica-gel technique. This crystal growth technique is especially suitable to produce relatively large crystals of sparingly soluble salts. To our knowledge this is the first time that this technique has been used to produce ikaite crystals. The gel was prepared using water from Laguna Potrok Aike, a lake in Southern Patagonia, Argentina. Water samples from this lake were collected in austral winter 2008 within the framework of the International Continental Scientific Drilling Program (ICDP) campaign 5022 (project PASADO). The evolution of the obtained ikaite crystals was 
followed by Raman spectroscopy at two different temperatures, 10 and $20^{\circ} \mathrm{C}$, once they were in contact with atmospheric air. Changes in the Raman spectra as a function of time provided valuable information that (i) evidenced the existence of different temperature-related reaction pathways and (ii) allowed us to propose a dissolutionrecrystallization mechanism for the pseudomorphic transformation of ikaite into calcite. The possible implications of this mechanism for the reliability of paleoclimatic conditions extrapolated from geochemical characteristics of glendonites are discussed.

\section{Experimental procedure}

\subsection{Crystallization method}

Crystal growth experiments were conducted using a set-up that involves the diffusion of $\mathrm{CaCl}_{2}$ through silica hydrogel in a test tube $(150 \mathrm{~mm}$ tall $\mathrm{x} 16 \mathrm{~mm}$ with $14 \mathrm{~mm}$ inner diameter). A solution (14 ml) was prepared by mixing a sodium silicate solution $\left(\mathrm{Na}_{2} \mathrm{SiO}_{3}\right)\left(\right.$ Merck KGaA, specific gravity $\left.=1.509 \mathrm{~g} / \mathrm{cm}^{3} ; \mathrm{pH}=11.2\right)$ with water from Laguna Potrok Aike, Patagonia (Argentina) and adding $1 \mathrm{~N} \mathrm{HCl}$ to reach a $\mathrm{pH}$ of 5.5 and poured in a test tube. After gelation occurred $8 \mathrm{ml}$ of $0.5 \mathrm{M} \mathrm{CaCl}_{2}$ aqueous solution were poured on top of the gel and the test tube was sealed with a hermetic cap. Water from Laguna Potrok Aike is characterized by a $\mathrm{pH}$ in the range between 8.7 and 9.0 and high phosphorus and magnesium concentrations, (Haberzettl et al., 2005; Zolitschka et al., 2006). The saturation state $(\Omega)$ with respect to calcite of the water used in the crystal growth experiments was $\sim 20$, which means that its saturation state with respect to aragonite was $\sim 14.5$ and it was slightly undersaturated with respect to ikaite.

Despite the high supersaturation with respect to both calcite and aragonite of water in Laguna Potrok Aike, none of these phases directly precipitate in this environment, which has been related to an inhibitory effect of the high concentration of phosphorus on their crystallization (Brooks et al., 1950; Buchardt et al., 1997). In this environment the crystallization of ikaite occurs seasonally, connected to high evaporation and water mixing events (Mayr et al., 2007). A summary of the chemistry of the lake water analysed by ion chromatography is given in Table 1. The lake water was transported to the laboratory at the University of Munich in airtight vessels, remaining at temperatures below $4^{\circ} \mathrm{C}$ during the whole process. 
The crystal growth experiments were maintained at $3 \pm 1^{\circ} \mathrm{C}$ in a refrigerating chamber. Upon starting the experiments, ikaite nucleation and crystal growth occured after the system became supersaturated with respect to this phase as a result of the diffusion through the gel of $\mathrm{Ca}^{2+}$ from the $\mathrm{CaCl}_{2}$ aqueous solution on top. The crystallization progress was monitored by optical microscopy (Leica). The first ikaite crystals were detected in the gel 10 days after the beginning of the crystal growth experiments.

\subsection{Characterization of the crystals and the reaction pathways}

Two months after observing the formation of the first crystals, the experiments were stopped. The obtained crystals were extracted from the gel and confirmed as ikaite by Raman spectroscopy. Moreover, Raman spectra were collected in a temperaturecontrolled room in situ on ikaite crystals to obtain information on the processes that they underwent in contact with air at two different temperatures $\left(10\right.$ and $\left.20^{\circ} \mathrm{C}\right)$. The extraction of the crystals from the gel was conducted at $4^{\circ} \mathrm{C}$. The Raman spectra were collected using a confocal Thermo Fischer DXR Raman Microscope, which has pointand-shoot Raman capability of one micrometer spatial resolution. The Raman instrument was calibrated for wavenumber position by analyzing a polished silicon standard at the beginning of each analysis session. The objective selected was of $10 \mathrm{x}$ magnification, with a numerical aperture of 0.9 , together with a laser source at $532 \mathrm{~nm}$ at $10 \mathrm{~mW}$ in a laser mode power at $100 \%$. The laser was always focused at a minimum depth of $5 \mu \mathrm{m}$ below the surface of the sample. The average spectral resolution of the Raman shift ranging from 70 to $3400 \mathrm{~cm}^{-1}$ was $2-4 \mathrm{~cm}^{-1}$, i.e., grating 900 lines/mm, and a spot size of $2 \mu \mathrm{m}$. The system was operated under OMNIC 1.0 software selecting working conditions such as pinhole aperture of $25 \mu \mathrm{m}$ and bleaching time of 1-2 s; four exposures averaged in 12 seconds each. Peak deconvolution was carried out using the software package Fityk (Wojdyr, 2010). XRD analysis was conducted on the sample whose Raman spectra were collected at $10^{\circ} \mathrm{C}$. The low amount of material recovered made this impossible for the sample whose Raman spectra were collected at $20^{\circ} \mathrm{C}$. XRD measurements were made on a STOE diffractometer using $\mathrm{Cu} \mathrm{K} \alpha 1$ radiation (40 $\mathrm{kV}, 30 \mathrm{~mA}$ ). The samples were scanned from 10 to $90^{\circ} 2 \theta$ at a rate of $0.42 \theta \mathrm{min}^{-1}$. The crystals were further studied by scanning electron microscopy (SEM; JEOL JSM 6400 F). The samples were mounted on a stub of metal with adhesive, coated with $40-60 \mathrm{~nm}$ of gold and then observed in the SEM. 


\subsection{Characteristics of the Raman spectrum of ikaite}

The characteristics of the Raman spectrum of ikaite were earlier reported by several researchers (Clarkston et al., 1992; Mikkelsen et al., 1999; Tlili et al., 2002; Coleyshaw et al., 2003; Shahar et al., 2005; Hu et al., 2014). Most of these studies were conducted on synthetic samples and report that the most intense band in the spectra appears between 1067 and $1074 \mathrm{~cm}^{-1}$ and corresponds to the symmetric stretching of the carbonate group. Another strong band that belongs to the internal in-plane C-O antisymmetric bending mode $\left(v_{4}\right)$ appears between 718 and $722 \mathrm{~cm}^{-1}$. Moreover, three to six bands corresponding to the lattice vibrations appear in the low frequency region located between 100 and $280 \mathrm{~cm}^{-1}$. Some of the Raman studies on ikaite as referenced above also reported the presence of the water modes, although poorly resolved and described in most of the cases as weak contributions located at $3000-3500 \mathrm{~cm}^{-1}$. A summary of published Raman data on ikaite is shown in Table 2.

\section{Results}

\subsection{Raman characteristic of the newly-synthesized ikaite}

The crystals obtained in the crystallization experiments are colourless and show a habit compatible with monoclinic symmetry. Figure 1a shows an optical image of one of these crystals. Immediately after crystals were recovered from the gel, Raman spectra were collected on clean areas of these crystals (region marked with a blue circle in Figure 1). Band positions in these spectra are summarized in Table 2. These Raman spectra are characterised by a very strong band at $1066 \mathrm{~cm}^{-1}$ and another less intense near $715 \mathrm{~cm}^{-1}$ (blue spectrum in Figure 2). These bands can be assigned to the symmetric stretching $\left(v_{1}\right)$ and the internal in-plane antisymmetric bending mode $\left(v_{4}\right)$ of the carbonate groups, respectively. The second most intense band in the spectrum can be seen at $199 \mathrm{~cm}^{-1}$ together with secondary peaks at 137 and $263 \mathrm{~cm}^{-1}$ which are interpreted as due to lattice vibrations. In the collected spectra, bands in the $v_{\mathrm{OH}}$ stretching region of $\mathrm{H}_{2} \mathrm{O}$ could be detected with very good resolution (Figure 3). Applying Fourier decomposition to this region (marked with the blue circle) allowed us to identify bands at $3165,3257,3336$, and $3432 \mathrm{~cm}^{-1}$. The comparison of features of 
these spectra to published Raman data of ikaite (see Table 2) shows that there is a good agreement in number of bands and approximate band wavelengths, confirming the crystals obtained in the growth experiments as ikaite. Nevertheless, it is important to highlight that ikaite Raman bands in this study show a clear shift toward lower frequencies compared to previously published data. This trait affects bands associated to both lattice vibrations and to carbonate modes. Most published Raman data of ikaite were taken on synthetic crystal crystallized from pure aqueous solutions. On the contrary, ikaite crystals in this study were synthesis from natural, chemically complex water that contains high concentrations of $\mathrm{Mg}$, phosphorus and sulfate, among others. In particular, the presence of phosphorous has been related to the inhibition of the crystallization of the stable $\mathrm{CaCO}_{3}$ phase calcite which eventually leads to the formation of metastable ikaite from Laguna Potrok Aike water, as explained above. The incorporation of small amounts of impurities could justify the observed shift in band positions (Buzgar and Apolei, 2009).

Raman spectra were also collected on regions of the crystals that showed signs of undergoing transformation (see for example the region marked with a red circle in Figure 1). In these spectra the most intense band appears at $1081 \mathrm{~cm}^{-1}$ with a shoulder at $1066 \mathrm{~cm}^{-1}$ (red spectrum in Figure 2). Moreover, two bands can be observed at 709 and $718 \mathrm{~cm}^{-1}$ in the region of the $v_{4}$ carbonate mode. Finally, in the region corresponding to the external vibrations it is possible to distinguish three bands now at 146, 199 and 277 $\mathrm{cm}^{-1}$, the latter being the most intense. The characteristics of these spectra could be explained as resulting from a combination of the band distributions of calcite and/or aragonite with that of ikaite. Although characteristics of carbonate modes in calcite and aragonite Raman spectra are very similar, the lattice vibrations corresponding to each polymorph are significantly different. Whereas the Raman spectrum of aragonite shows eleven to twelve bands between 100 and $300 \mathrm{~cm}^{-1}$, only two bands located around 155 and $281 \mathrm{~cm}^{-1}$ are typically found in calcite spectrum (see Table 3). The collected spectra show a small number of bands in the low frequency region and their positions match relatively well a combination of bands of ikaite and calcite, which leads us to discard that aragonite could be present. It is important to note that these spectra also show a shift of 4-6 cm $\mathrm{cm}^{-1}$ toward lower frequencies which equally affects to ikaite and calcite bands (see comparisons between data in this study and published data for ikaite (Table 2) and calcite (Table 3). As in the previous case, we attribute this shift to the 
incorporation of impurities in the structure of these phases. According to the relative intensities of bands assigned to ikaite and calcite, we conclude that the region in the ikaite crystal where the Raman spectra were taken has undergone an almost complete transformation into calcite, ikaite appearing as a minor component. This is further confirmed by the characteristics of the spectra in the wavelength region where the water bands appear (red spectrum in Figure 3). These bands could be identified by Fourier decomposition; they appeared very weak. It is important to note that the experimental approach followed would prevent the detection of short-lived amorphous calcium carbonate (ACC), had it formed at very early stages of the transformation.

On the same crystal, regions were found that showed Raman spectra indicating fresh ikaite, while other regions corresponded to a mixture of mainly calcite and some ikaite. This coexistence indicates that, as soon as ikaite crystals are extracted from the gel and put in contact with the laboratory air, their transformation into calcite starts and this transformation involves the nucleation of calcite crystals on the surface of ikaite.

\subsection{Processes undergone by ikaite crystals in contact with air}

In order to gain insight into the mechanism that controls the progress of ikaite transforming into calcite in contact with atmospheric air and to identify different possible reaction pathways, the process was monitored by collecting Raman spectra at two different temperatures: $10^{\circ} \mathrm{C}$ and $20^{\circ} \mathrm{C} \pm 2{ }^{\circ} \mathrm{C}$.

The crystal analysed in the experiment conducted at $10^{\circ} \mathrm{C}$ is shown in Figure 1 . The image in Figure 1a was taken at the beginning of the transformation process, while the image in Figure 1b was taken 24 hours after the crystals were recovered from the gel Figures 4 and 5 show the Raman spectra collected in this experiment. Spectra were collected every 15 minutes while the sample was held at $10^{\circ} \mathrm{C}$. However, for the sake of simplicity only three spectra corresponding to the beginning of the process (in blue), an intermediate stage (in green) and the final stage (in red) are shown. The time elapsed between the collection of the blue and the green spectra were 150 minutes. The red spectrum was collected 5 hours after the beginning of the experiment. Plots in Figure 4 are focused on the wavelength region $100-300 \mathrm{~cm}^{-1}$ corresponding to the lattice vibrations. Figure 4a shows the typical lattice modes assigned to ikaite (Table 2). The 
higher intensity bands are located at 137, 199 and $263 \mathrm{~cm}^{-1}$. In Figure 4b, bands in the lattice modes region can be explained as the result of a combination of the lattice vibration bands of ikaite and calcite, with the former dominating the green spectrum. In this case, the band located at $263 \mathrm{~cm}^{-1}$ and assigned to ikaite disappear and two new bands at 146 and $274 \mathrm{~cm}^{-1}$, corresponding to calcite (Table 3), start to emerge. Finally, bands in Figure 4c can be explained again as a result of a combination of bands of ikaite and calcite, with the latter gaining importance and dominating the red spectrum. Band distribution in this region does not support the presence of aragonite or vaterite. The plot in Figure 5 is focused on the wavelength region corresponding to the area of the symmetric stretching of the carbonate group. The spectra in this plot show the Raman intensities normalized to the $v_{1}$ band for a better comparison. In the blue spectrum the $v_{1}$ band of the ikaite at $1066 \mathrm{~cm}^{-1}$ appears very intense. The deconvolution of the bands also evidences the presence of a weak shoulder at $1081 \mathrm{~cm}^{-1}$ which can be assigned to calcite (the intense band $v_{1}$ corresponding to the symmetric stretching of $\mathrm{CO}_{3}$ group in synthetic calcite is usually found in the range $1080-1085 \mathrm{~cm}^{-1}$ ), indicating that a small amount of this phase has already formed at the very beginning of the experiment. In the green spectrum an intense band at $1066 \mathrm{~cm}^{-1}$ and a marked shoulder at $1081 \mathrm{~cm}^{-1}$ indicate the presence of both ikaite and calcite. Moreover, the relative intensity of both bands indicates that the amount of calcite has significantly increased compared to the first spectrum. Finally, in the spectrum in red the most intense band is located around $1081 \mathrm{~cm}^{-1}$ and a small shoulder can be distinguished at $1066 \mathrm{~cm}^{-1}$, indicating that calcite is now the predominant phase and the region of the crystal explored only contains a small amount of ikaite as a relict.

Figure 6 shows a SEM image of the crystal used in the experiment conducted at $20^{\circ} \mathrm{C}$. In this case, the transformation of ikaite proceeded very rapidly. Due to the promptness of the process, only two spectra could be collected; one at the beginning of the process, which shows the same bands as those in the blue spectrum in Figure 2, and the other one 10 minutes later, which shows that ikaite transformation in anhydrous $\mathrm{CaCO}_{3}$ phases was complete in the region of the crystal explored. The points marked as a, b and c in Figure 6 were analyzed in the transformed sample. The Raman spectrum collected on point a in Figure 6, where a rhombohedral crystal can be distinguished, shows features compatible with calcite and aragonite (red spectrum in Figure 7): an intense band at $1081 \mathrm{~cm}^{-1}$ and a band at $706 \mathrm{~cm}^{-1}$ that can be assigned to the $v_{1}$ symmetric 
stretching and the $v_{4}$ bending mode of the carbonate group, respectively. The bands at 148 and $275 \mathrm{~cm}^{-1}$ are in agreement with calcite lattice modes confirming this crystal as calcite. The spectrum obtained for point $\mathrm{c}$, at the surface of the sample, has the same characteristics as the one for the rhombohedral calcite crystals. Finally, the spectrum collected on point $\mathrm{b}$ in figure 6 , where a spherical object can be distinguished (black spectrum), shows a clear doublet for the $v_{1}$ symmetric stretching at 1072 and $1086 \mathrm{~cm}^{-1}$ (inset in Figure 7); the second most intense band corresponding to the lattice modes is located at $328 \mathrm{~cm}^{-1}$ and is accompanied by three weak bands at 274, 200 and $148 \mathrm{~cm}^{-1}$ as well as by the doublet in the bending mode $v_{4}$ area between 730 and $750 \mathrm{~cm}^{-1}$. The characteristics of this spectrum are in agreement with the spherical object being vaterite (Gauldie et al., 1997; Carteret et al., 2009; Wehrmeister et al., 2010).

The characteristics of the spectra collected during the transformation of ikaite in contact with air indicate that both the kinetics of the reaction and the reaction pathway vary strongly with temperature. At $20^{\circ} \mathrm{C}$ the process proceeds much more rapidly than at $10^{\circ} \mathrm{C}$ and involves the formation of metastable vaterite together with calcite. Raman spectra collected on the sample maintained at $20^{\circ} \mathrm{C}$ for 24 hours after the beginning of the experiment confirm that the metastable vaterite is still present in the system.

\subsection{SEM observations of transformed crystals}

Ikaite crystals obtained from the first experiment (Raman analysis carried out at $10^{\circ} \mathrm{C}$ ) were observed by SEM 24 hours after extraction from the gel (Figure 8). These crystals were kept at room temperature after finishing their Raman analysis. Their complete transformation into calcite was confirmed by XRD. As can be seen in Figure 8, the external shape of the ikaite crystals was preserved during their transformation into

calcite. A closer inspection of these pseudomorphs shows that their surface is rough and porous (Figure 8b). Moreover, due to their high porosity these pseudomorphs were extremely fragile. As a result, the crystals transformed at $20^{\circ} \mathrm{C}$ readily disintegrated into powder as they were handled, which made it impossible to take SEM images of these crystals. Moreover, enough material could not be recovered to carry out XRD analyses on this sample. 


\section{Discussion}

\subsection{Reaction pathways}

Raman spectra collected on ikaite samples at 10 and $20^{\circ} \mathrm{C}$ show that ikaite readily transforms into anhydrous $\mathrm{CaCO}_{3}$ phases following temperature-dependent reaction pathways. Thus, while ikaite directly transforms into calcite at $10^{\circ} \mathrm{C}$, the transformation at $20^{\circ} \mathrm{C}$ involves the formation of an intermediate metastable phase, vaterite, and occurs more rapidly. This difference in reaction pathways can be interpreted as resulting from the predominance of kinetic over thermodynamic factors at $20^{\circ} \mathrm{C}$, as the system is further from equilibrium. The formation of vaterite at $20^{\circ} \mathrm{C}$ is, thus, in agreement with the "Law of Successive Reactions" (Ostwald, 1897), which predicts the formation of those phases with lower activation energy barriers as intermediate steps toward equilibrium in kinetically controlled transformations. It is important to note that, although of lower intensity, bands compatible with vaterite are still present in the Raman spectrum collected on the ikaite sample maintained at $20^{\circ} \mathrm{C}$ for 24 hours after the beginning of the experiment. The preservation of this intermediate metastable phase is most likely the consequence of a sluggish transformation of vaterite into calcite under the experimental conditions considered.

\subsection{Replacement mechanism}

In the experiments conducted, the transformation of ikaite single crystals occurs in contact with atmospheric air, in principle in the absence of an aqueous fluid phase. However, it is not likely that this transformation can occur in the solid state at the temperatures considered since it involves a total reorganization of the crystal structure.

In fact, the calcite aggregates formed after ikaite show characteristics of a mineral replacement that occurs through a coupled dissolution-crystallization process: it occurs with preservation of the external shape and generation of a high amount of porosity (Putnis, 2002). There are other mineral replacement processes that are interpreted to occur through a coupled dissolution-crystallization mechanism even when water is virtually absent in the system. For example, this is the case of the carbonation of portlandite $\left(\mathrm{Ca}(\mathrm{OH})_{2}\right)$, which pseudomorphically transforms into calcite in contact with air (Ruiz-Agudo et al. 2013). Beruto and Botter (2000) concluded that a thin liquid-like layer of water molecules adsorbs on portlandite crystal surfaces in contact with 
atmospheric air. This nanometric layer provides the means to initiate the coupled dissolution-crystallization process. Since additional water molecules are generated as byproducts of the carbonation process, once it is triggered by adsorbed water, the mineral replacement progresses easily (Ruiz-Agudo et al. 2013). We propose a similar mechanism for the transformation of ikaite into calcite (or calcite/vaterite mixtures). In the present case two factors would further contribute to the feasibility of the dissolutioncrystallization mechanism: (i) The initially lower temperature of ikaite crystals $\left(<4^{\circ} \mathrm{C}\right)$ with respect to the environment $\left(10\right.$ or $20^{\circ} \mathrm{C}$, depending on the experiment), which favours the condensation of atmospheric water on their surface, and (ii) the high amount of water released (6 mols of water for each mol of ikaite transformed) as ikaite transforms into an anhydrous calcium carbonate phase.

The coupled dissolution-crystallization mechanism is consistent with the presence of two intense broad bands that can be assigned to liquid water in the Raman spectrum as soon as the experiment is initiated, irrespective of the temperature at which it is conducted (Figure 9). The more intense of these two bands is located in the range 3000 $-3300 \mathrm{~cm}^{-1}$ and is interpreted as the symmetric stretching vibration of water. The second band, interpreted as the antisymmetric stretching, appears at $3445 \mathrm{~cm}^{-1}$. These broad bands are difficult to deconvolve but show very different characteristics from those of bound water in ikaite, which are sharp (Walfaren, 1967; Dubessy et al., 1992). We interpret that these two broad bands correspond to water adsorbed on ikaite surface. In the case of ikaite, the band located around $3500 \mathrm{~cm}^{-1}$ is always the more intense of the two water bands. Raman spectra depicted in Figure 10 evidence the progressive decrease in intensity of ikaite structural water bands as the transformation of ikaite into calcite advances. Changes observed in the water bands are in good agreement with adsorbed water initiating the dissolution of which results in the release of more water molecules as ikaite structure is destabilized. This chain of events enhances the progressive breakdown of ikaite and its replacement by anhydrous phases.

Coupled dissolution-crystallization mineral replacement reactions can start as soon as the dissolution of a few monolayers of a crystal (ikaite) results in an interfacial boundary layer of fluid supersaturated with respect to one or more stable phases (vaterite/calcite) (Putnis and Putnis, 2007; Ruiz-Agudo et al. 2014). Calcite and calcite/vaterite pseudomorphs after ikaite are highly porous. This porosity compensates 
for the overall solid volume reduction that results from the much smaller molar volume of ikaite in comparison to calcite (and vaterite), thereby allowing the preservation of the external morphology of ikaite crystals. However, pseudomorphs formed at $20^{\circ} \mathrm{C}$ are more porous and fragile than those formed at $10^{\circ} \mathrm{C}$. This can be explained taking into account the rate at which the water released during the transformation of ikaite into anhydrous $\mathrm{CaCO}_{3}$ phases evaporates. The presence of water between the boundaries of crystals constituting the pseudomorph will facilitate their sintering. Water evaporation will occur more rapidly at $20^{\circ} \mathrm{C}$ than at $10^{\circ} \mathrm{C}$ and it explains a poorer sintering and consequently more fragile pseudomorphs when the mineral replacement occurs at $20^{\circ} \mathrm{C}$.

\subsection{Implications for glendonite as a lacustrine palaeoenvironmental proxy}

The transformation of ikaite to calcite within 5 hours after a change of temperature from 4 to $10^{\circ} \mathrm{C}$ led to the preservation of the original ikaite crystal shape in our experiments. In contrast, a more rapid transformation took place when the ikaite transformed at $20^{\circ} \mathrm{C}$. In the latter case the pseudomorphs were extremely fragile and rapidly disintegrated into calcite powder. These observations suggest that the amount and velocity of a temperature increase may play an important role in the preservation of glendonites in the sediment record. At present calcite pseudomorphs after ikaite are known from two lakes in Patagonia, Laguna Cháltel (Ohlendorf et al., 2014) and Laguna Potrok Aike (Oehlerich et al., 2013). At Laguna Potrok Aike ikaite and its pseudomorphs were only observed during winter, and pseudomorphs are absent in the sediment record. It was, thus, suggested that the pseudomorphs were rapidly disintegrating to $\mu \mathrm{m}$-sized calcite crystals, which are finely dispersed in the sediment (Oehlerich et al., 2013). In contrast, pseudomorphs after ikaite are frequent in the sediment record of Laguna Cháltel, but, due to the remote geographical position of the lake on a mountain plateau, ikaite precipitation during the cold season was not yet observed. While surface water temperatures range between 1 and $8^{\circ} \mathrm{C}$ in Laguna Cháltel (Ohlendorf et al., 2014), they range between 3 and $12^{\circ} \mathrm{C}$ in Laguna Potrok Aike (Oehlerich et al., 2013). The differential preservation of ikaite-derived anhydrous calcium carbonate may thus be climatically controlled. However, only in Laguna Potrok Aike modern ikaite precipitation was observed. There, the ikaite crystals precipitate on surfaces in the water column only during the winter months and were never observed during the warm season at water temperatures above $7{ }^{\circ} \mathrm{C}$ (Oehlerich et al., 2013). Additionally, differential 
transformation times in our experiments led to different anhydrous calcium carbonate phases. The metastable vaterite occurred only during rapid transformation at $20^{\circ} \mathrm{C}$ and not at $10^{\circ} \mathrm{C}$. However, the transformation in the lake water may follow different pathways than a transformation due to exposure to air. Although, clearly, more field studies are needed to transfer our experimental data to conditions in lake systems, our data already imply a potential linkage between ikaite pseudomorph preservation and lake-water temperature which could be of use for paleoclimatic interpretation.

\section{Conclusion}

Ikaite crystals have been grown in a natural aqueous solution at $2-4^{\circ} \mathrm{C}$ using the active silica gel method. The transformation of ikaite at 10 and $20^{\circ} \mathrm{C}$ in contact with atmospheric air has been followed by Raman spectroscopy. Raman spectra collected immediately after starting the transformation experiments showed the characteristic features of ikaite, including the water bands. Different temperature-dependent reaction pathways were identified based on the appearance of and intensity evolution of new bands. While ikaite directly transforms into calcite at $10{ }^{\circ} \mathrm{C}$ in contact with air, at $20^{\circ} \mathrm{C}$ this transformation involves the formation of intermediate, metastable vaterite, which is still present in the system together with calcite 24 hours after the beginning of the experiment. Irrespective of the reaction pathway followed, the external shape of ikaite was preserved after transformation and involved the generation of a large volume of porosity that accounts for the high difference in molar volume between ikaite and calcite. A transformation mechanism involving a coupled dissolution-crystallization reaction is proposed to account for both the characteristics of calcite pseudomorphs after ikaite and the features of the Raman spectra collected in the experiments.

\section{Acknowledgements}

The authors acknowledge the financial support provided by the Deutsche Forschungsgemeinschaft (DFG MA 4235/4-1 to C.M.) and the Ministerio de Economía y Competitividad, Spain (Project CGL2013-47988-C2-1-P). Nuria Sánchez-Pastor acknowledges the support obtained from the post-doctoral fellowship from the Alexander von Humboldt Foundation. The collection of the lake water was made 
possible also by DFG-grants in the framework of the ICDP drilling project PASADO. Insightful comments by three anonymous reviewers are gratefully acknowledged.

\section{References}

Adkins J. F., Mclntyre, K. and Schrag D. P. (2002) The salinity, temperature, and $\delta^{18} \mathrm{O}$ of the glacial deep ocean. Science 298, 1769-1773.

Beruto D. T. and Botter R. (2000) Liquid-like H2O adsoption layers to catalyze the $\mathrm{Ca}(\mathrm{OH}) 2 / \mathrm{CO} 2$ solid-gas reaction and to form a non-protective solid product layer at $20^{\circ}$ C. J. Eur. Ceram. Soc. 20, 497-503.

Bischoff W. D., Sharma, S. K. and Mackenzie, F. T. (1985) Carbonate ion disorder in synthetic and biogenic magnesian calcites: A Raman spectral study. Am. Mineral. 70, 581-589.

Bischoff J. L., Currey D. R. and Rosenbauer R. J. (1993a) The solubility and stabilization of ikaite from 0 to $25^{\circ} \mathrm{C}$ : Environmental and paleoclimatic implications for thinolite tufa. J. Geol. 101, 21-33.

Bischoff J. L., Scott S., Rosenbauer R. J., Fitzpatrick J. A. and Stafford J. R. (1993b)

Ikaite precipitation by mixing of shoreline springs and lake water, Mono Lake, California, USA. Geochim. Cosmochim. Acta 57, 3855-3865.

Brooks R., Clark L. M. and Thurston E. F. (1950) Calcium carbonate and its hydrates. Philos. Trans. R. Soc. A243, 145-167.

Buchardt B., Seaman P., Stockmann G., Vous M., Wilken U., Düwel L., Kristiansen A., Jenner C., Whiticar M. J., Kristensen R. M., Petersen G. H. and Thorbjørn L. (1997) Submarine columns of ikaite tufa. Nature 390, 129-130.

Buzgar N. and Apolei A. I. (2009) The Raman study of certain carbonates. An Stiint Univ AI I Cuza Iasi Sect III C Stiint Econ. 2, 97-112. 
Carteret C., Dandeu A., Moussaoui S., Muhr H., Humbert B. and Plasari E. (2009) Polymorphism studied by lattice phonon Raman spectroscopy and statistical mixture analysis method. Application to calcium carbonate polymorphs during batch crystallization. Cryst. Growth Des. 9, 807-812.

Coleyshaw E. E., Crump G. and Griffith W. P. (2003) Vibrational spectra of the hydrated carbonate minerals ikaite, monohydrocalcite, landsfordite and nesquehonite. Spect. Acta Part A 59, 2231-2239.

Clarkson J. R., Price T. J. and Adams C. J. (1992) Role of metastable phases in the spontaneous precipitation of calcium carbonate. J. Chem. Soc. Far. Trans. 88, 243-249.

De Lurio J. L. and Frakes L. A. (1999) Glendonites as a paleoenvironmental tool: Implications for early Cretaceous high latitude climates in Australia. Geochem. Cosmochim. Acta 63, 1034-1048.

Dickens B. and Brown H. (1970): The crystal structure of calcium carbonate hexahydrate at $-120^{\circ}$ C. Inorg. Chem. 9, 480-486.

Dieckmann G. S., Nehrke G., Uhlig C., Göttlicher J., Gerland S., Granskog M. A. and Thomas D. N. (2010) Brief communication: Ikaite $\left(\mathrm{CaCO}_{3} \cdot 6 \mathrm{H}_{2} \mathrm{O}\right)$ discovered in Artic sea ice. The Cryosphere 4, 227-230.

Dubessy J., Boiron M-C., Moissette A., Monnin C. and Sretenskaya N. (1992) Determinations of water, hydrates and $\mathrm{pH}$ in fluid inclusions by micro-Raman spectrometry. Eur. J. Min. 4, 885-894.

Gaines R. V., Skinner H. C. W., Foord E. R., Mason B. and Rosenzweig A. (1997) Dana’s New Mineralogy (eds. John Wiley \& Sons). New York. pp. 1819.

Gauldie R. W., Sharma S. K. and Volk, E. (1997) Micro-Raman spectral study of vaterite and aragonite ooliths of the Coho Salmon, Oncorhynchus kisutch. Comp. Biochem. Physiol. 118A, 753-757. 
Haberzettl T., Fey M., Lücke A., Maidana N., Mayr C., Ohlendorf C., Schäbitz F., Schleser, G. H., Wille M. and Zolitschka B. (2005) Climatically induced lake level changes during the last two millennia as reflected in sediments of Laguna Potrok Aike, southern Patagonia (Santa Cruz, Argentina). J. Paleolimnol. 33, 283-302.

Hesse K. F,. Küppers H. and Suess E. (1983) Refinement of the structure of Ikaite, $\mathrm{CaCO}_{3} \cdot 6 \mathrm{H}_{2} \mathrm{O}$. Z. Kristallogr. 163, 227-231.

Hu Y. -B., Wolf-Gladrow D. A., Dieckmann G. S., Völker C. and Nehrke G. (2014) A laboratory study of ikaite $\left(\mathrm{CaCO}_{3} \cdot 6 \mathrm{H}_{2} \mathrm{O}\right)$ precipitation as a function of $\mathrm{pH}$, salinity, temperature and phosphate concentration. Mar. Chem. 162, 10-18.

Ito T. (1996) Ikaite from cold spring water at Shiowakka, Japan. J. Min. Pet. Econ. Geology 91, 209-219.

Ito T. (1998) Factors controlling the transformation of natural ikaite from Shiowakka, Japan. Geochem. J. 32, 267-273.

Jansen J. H. F., Woensdregt C. F., Kooistra M. J. and van der Gaast S. J. (1987) Ikaite pseudomorphs in the Zaire deep see fan: An intermediate between calcite and porous calcite. Geology 15, 245-248.

Larsen D. (1994) Origin and paleoenvironmental significance of calcite pseudomorphs after ikaite in the Oligocene Creede Formation, Colorado. J. Sediment. Res. 64, 593603.

Last F. M., Last W. M., Fayek M. and Halden N. M. (2013) Occurrence and significance of a cold-water carbonate pseudomorph in microbialites from a saline lake. J. Paleolimnol. 50, 505-517.

Lu Z., Rickaby R. E. M., Kennedy H., Kennedy P., Pancost R. D., Shaw S., Lennie A., Wellner J. and Anderson J. B. (2012) An ikaite record of late Holocene climate at the Antartic Peninsula. Earth Planet. Sc. Let. 325-326, 108-115. 
Marland G. (1975) The stability of $\mathrm{CaCO}_{3} \cdot 6 \mathrm{H}_{2} \mathrm{O}$ (Ikaite). Geochim. Cosmochim. Acta 39, 83-91.

Mayr C., Lücke A., Stichler W., Trimborn P., Ercolano B., Oliva G., Ohlendorf C., Soto J., Fey M., Haberzettl T., Janssen S., Schäbitz F., Schleser G. H., Wille M. and Zolitschka B. (2007). Precipitation origin and evaporation of lakes in semi-arid Patagonia (Argentina) inferred from stable isotopes (d18O, d2H). J. Hydrol. 334, 53-63.

Mikelsen A., Andersen A. B., Engelsen S. B., Hansen H. C. B., Larsen O. and Skibsted L. H. (1999) Presence and dehydration of ikaite, calcium carbonate Hexahydrate, in frozen shrimp shell. J. Agric. Food Chem. 47, 911-917.

Nomura D., Assmy P., Nehrke G., Granskog M. A., Fischer M., Dieckmann G. S., Fransson A., Hu Y. and Schnetger B. (2013) Characterization of ikaite $\left(\mathrm{CaCO}_{3} \cdot 6 \mathrm{H}_{2} \mathrm{O}\right)$ crystals in first-year Artic sea ice north of Svalbard. Ann. Glaciol. 62, 125-131.

Oehlerich M., Mayr C. C., Griesshaber E., Lücke A., Oeckler O. M., Ohlendorf C., Schmahl W. W. and Zolitschka B. (2013) Ikaite precipitation in a lacustrine environment - implications for palaeoclimatic studies using carbonates from Laguna Potrok Aike (Patagonia, Argentina). Quaternary Sci. Rev. 71, 46-53.

Ohlendorf C., Fey M., Massaferro J., Haberzettl T., Laprida C., Lücke A., Maidana N., Mayr C., Oehlerich M., Ramón Mercau J., Wille M., Corbella H., St-Onge G., Schäbitz F. and Zolitschka B. (2014) Late Holocene hydrology inferred from lacustrine sediments of Laguna Cháltel (southeastern Argentina). Palaeogeogr. Palaeocl. 411, $229-248$.

Omelon C. R., Pollard W. H. and Marion G. M. (2001) Seasonal formation of ikaite $\left(\mathrm{CaCO}_{3} \cdot 6 \mathrm{H}_{2} \mathrm{O}\right)$ in saline spring discharge at Expedition Fiord, Canadian High Artic: assessing conditional constrains for natural crystal growth. Geochim. Cosmochim. Acta 65, 1429-1437.

Ostwald W. (1897) Studien über die Bildung und Umwandlung fester Körper. 1. Abhandlung: Übersättigung und Überkaltung. Z. Phys. Chem. 22, 289-330. 
Pauly H. (1963) “Ikaite”, a new mineral from Greenland. Arctic 16, 263-264.

Pelouze M. J. (1865) Sur une combinaison nouvelle d'eau et de carbonate de chaux. Chem. Rev. 60, 429-431.

Putnis A. (2002) Mineral replacement reactions: From macroscopic observations to microscopic mechanisms. Min. Mag. 66, 689-708.

Putnis A. and Putnis C. V. (2007) The mechanism of reequilibration of solids in the presence of a fluid phase. J. Sol. State Chem. 180, 1783-1786.

Rickaby R. E. M., Shaw S., Bennitt G., Kennedy H., Zabel M. and Lennie A. (2006) Potential of ikaite to record evolution of oceanic $\delta^{18} \mathrm{O}$. Geology 34, 497-500.

Ruiz-Agudo E., Kudlacz K., Putnis C. V., Putnis A. and Rodríguez-Navarro C. (2013) Dissolution and carbonation of portlandite $[\mathrm{Ca}(\mathrm{OH}) 2]$ single crystals. Environ. Sci. Technol. 47, 11342-11349.

Ruiz-Agudo E., Putnis C. V. and Putnis A. (2014) Coupled dissolution and precipitation at mineral-fluid interfaces: Chem. Geol. 383, 132-146.

Schrag D. P. and DePaolo D. J. (1993) Determination of $\delta^{18} \mathrm{O}$ of seawater in the deep ocean during the Last Glacial Maximum. Paleoceanography 8, 1-6.

Shahar A., Bassett W. A., Mao H-K., Chou I-M. and Mao W. (2005) The stability and Raman spectra of ikaite, $\mathrm{CaCO}_{3} \cdot 6 \mathrm{H}_{2} \mathrm{O}$, at high pressure and temperature. Am. Mineral. 90, 1835-1839.

Soldati A. L., Jacob D. E., Wehrmeister U. and Hofmeister W. (2008) Structural characterization and chemical composition of aragonite and vaterite in freshwater cultured pearls. Min. Mag. 72, 579-592. 
Suess E., Balzer W., Hesse K. F., Müller P. J., Ungerer C. A. and Wefer G. (1982)

Calcium carbonate hexahydrate from organic-rich sediments of the Antarctic Shelf: Precursors of Glendonites. Science 216, 1128-1131.

Swainson I. P. and Hammond R. P. (2001) Ikaite, $\mathrm{CaCO}_{3} \cdot 6 \mathrm{H}_{2} \mathrm{O}$ : Cold comfort for glendonites as paleothermometers. Am. Mineral. 86, 1530-1533.

Tang C. C., Thompson S. P., Parker J. E., Lennie A. R., Azough F. and Kato K. (2009) The ikaite-to-vaterite transformation: new evidence from diffraction and imaging. $J$. Appl. Crystallogr. 42, 225-233.

Tlili M. M., Ben Amor M., Gabrielli C., Joiret S. and Rousseau P. (2001) Characterization of $\mathrm{CaCO}_{3}$ hydrates by micro-Raman spectroscopy. J. Raman Spectrosc. 33, 10-16.

Walfaren G.E. (1967) Raman Spectral Studies of the Effects of Temperature on Water Structure. J. Chem. Phys. 47, 114-126.

Wehrmesister U., Soldati A. L., Jacob D. E. Häger T. and Hofmeister W. (2010) Raman spectroscopy of synthetic, geological and biological vaterite: a Raman spectroscopic study. J. Raman Spectrosc. 41, 193-201.

Wojdyr M. (2010) Fityk: a general-purpose peak fitting program. J.Appl. Cryst. 43, 1126-1128.

Zolitschka B., Schäbitz F., Lücke A., Corbella H., Ercolano B., Fey M., Haberzettl T., Janssen S., Maidana N., Mayr C., Ohlendorf C., Oliva G., Paez M. M., Schleser G. H., Soto J., Tiberi P. and Wille M. (2006) Crater lakes of the Pali Aike Volcanic Field as key sites for paleoclimatic and paleoecological reconstructions in southern Patagonia, Argentina. J. South Amer. Earth Sci. 21, 294-309. 


\section{Figure Captions}

Fig. 1. (a) Ikaite crystal showing an incipient transformation at the surface. The image was taken with the Raman microscope immediately after the crystal was recovered from the gel. Raman spectra were collected on clean areas (blue circle) and areas that showed signs of have started to undergo transformation (red circle). (b) Calcite pseudomorph after ikaite used to study the slow replacement process.

Fig. 2. Raman spectra displaying the internal and external vibration modes of the areas marked with a blue and a red circle in Figure 1. The area marked blue shows the typical bands for the untransformed ikaite crystal; the area marked red shows partial transformation to calcite crystals.

Fig. 3. Raman spectra of the stretching vibrations of the $\mathrm{OH}$ groups of water of the areas marked with a blue and a red circle in the crystal in Figure 1. Positions of the deconvolved bands are color-coded with respect to their spectral traces.

Fig. 4. Raman spectra of the lattice vibrations region showing the evolution of the slow transformation reaction of ikaite to calcite at $10^{\circ} \mathrm{C}$. (a) Spectrum taken at the beginning of the experiment showing the ikaite lattice modes. (b) Intermediate stage showing a combination of the lattice vibration bands of ikaite and calcite. (c) Final stage where calcite bands dominates the spectrum.

Fig. 5. Raman spectra of the symmetric C-O stretching region showing the evolution of the slow transformation reaction of ikaite to calcite at $10^{\circ} \mathrm{C}$. See text for details.

Fig. 6. SEM image showing a calcite/vaterite pseudomorph after ikaite from the experiment carried out to study the fast replacement of ikaite by calcite and vaterite at $20^{\circ} \mathrm{C}$. The points marked as (a) on a rhombohedral crystal and (c) on the surface were analysed by Raman spectroscopy and show bands compatible with calcite and the point marked as b on a spherical crystal shows clear bands corresponding to vaterite. The Raman Spectra can be seen in Figure 6. 
Fig. 7. External and internal vibrations of the calcite and vaterite crystals generated after the fast transformation of ikaite to calcite and vaterite at $20^{\circ} \mathrm{C}$. The inset shows a close look at the symmetric stretching region where clear differences between calcite and vaterite can be seen.

Fig. 8. (a) SEM image of a calcite pseudomorph after ikaite showing the generation of porosity. The transformation took place at $10^{\circ} \mathrm{C}$ and the images were taken 24 hours after the crystal was removed from the gel. (b) Closer look of the surface of crystal in Figure $7 \mathrm{a}$.

Fig. 9. Raman spectra of the liquid and bonded water modes corresponding to the transformation process of ikaite crystals to calcite/vaterite. The two sharp and strong bands in orange correspond to the bonded water in the ikaite structure and the two broad bands in lila can be assigned to liquid water appearing as a consequence of the transformation process into the anhydrous phases.

Fig. 10. Series of Raman spectra taken during monitoring of ikaite transformation showing shifts of peaks and changes in intensity in the range from 2800 to $3700 \mathrm{~cm}^{-1}$ that are related to water. The progressive intensity decrease of the structural water bands indicate how the transformation of ikaite into calcite advances in time. 


\section{TABLES}

Table 1. Composition of the water from Laguna Potrok Aike in Argentina, Patagonia (data from Zolitschka et al., 2006).

\begin{tabular}{|c|c|}
\hline pH & 8.7 \\
\hline Electric conductivity $(\mu \mathrm{S} / \mathrm{cm})$ & 2970 \\
\hline Salinity (\%o) & 1.4 \\
\hline Alkalinity (mmol/l) & 11.9 \\
\hline $\mathrm{Cl}^{-}(\mathrm{mmol} / \mathrm{l})$ & 18.2 \\
\hline $\mathrm{NO}_{3}^{-}(\mu \mathrm{mol} / \mathrm{l})$ & 27.9 \\
\hline $\mathrm{SO}_{4}{ }^{2-}(\mathrm{mmol} / \mathrm{l})$ & 0.27 \\
\hline Total $\mathbf{P}(\mu \mathrm{m} / \mathrm{l})$ & 116 \\
\hline $\mathrm{Fe}(\mu \mathrm{m} / \mathrm{l})$ & 0.2 \\
\hline $\mathrm{Na}(\mathrm{mmol} / \mathrm{l})$ & 20.7 \\
\hline $\mathrm{Mg}(\mathrm{mmol} / \mathrm{l})$ & 2.96 \\
\hline $\mathrm{Si}(\mu \mathrm{mol} / \mathrm{l})$ & 24.9 \\
\hline $\mathrm{K}(\mathrm{mmol} / \mathrm{l})$ & 0.81 \\
\hline $\mathrm{Ca}(\mathrm{mmo} / \mathrm{l})$ & 0.85 \\
\hline $\operatorname{Mn}(\mu \mathrm{mol} / \mathrm{l})$ & 0.04 \\
\hline Al $(\mu \mathrm{mol} / \mathrm{l})$ & 0.19 \\
\hline
\end{tabular}


Table 2. Raman band positions (wavenumber in $\mathrm{cm}^{-1}$ ) of ikaite from literature and this study.

\begin{tabular}{|c|c|c|c|c|}
\hline & $\begin{array}{l}\text { Lattice } \\
\text { modes }\end{array}$ & $\begin{array}{l}v_{4} \text { in-plane } \\
\text { bending }\end{array}$ & $\begin{array}{l}\mathrm{v}_{1} \text { symmetric } \\
\text { streching }\end{array}$ & $\begin{array}{l}\mathrm{H}_{2} \mathrm{O} \\
\text { stretching }\end{array}$ \\
\hline (Mikkelsen et al., 1999) & $\begin{array}{l}203,220 \\
278\end{array}$ & 719 & 1070 & n.o. \\
\hline (Tlili ert al., 2002) & n.o. & 718 & 1070 & $\begin{array}{l}3120,3270 \\
3434\end{array}$ \\
\hline (Coleyshaw et al., 2003) & n.o. & 722 & 1072 & $\begin{array}{l}3182,3240 \\
3423\end{array}$ \\
\hline (Hu et al., 2014) & $\begin{array}{l}137,154 \\
180,200 \\
260,280\end{array}$ & 718 & 1071 & n.o. \\
\hline This study & $\begin{array}{l}116,137, \\
156,183, \\
199,214, \\
263\end{array}$ & 715 & 1066 & $\begin{array}{l}3165,3257 \\
3336,3432\end{array}$ \\
\hline
\end{tabular}

* n.o. = not observed 
Table 3. Raman band positions (wavenumber in $\mathrm{cm}^{-1}$ ) of calcite, aragonite and vaterite from literature and this study.

\begin{tabular}{|c|c|c|c|c|c|c|c|c|c|c|}
\hline & \multicolumn{3}{|c|}{ Calcite } & \multicolumn{3}{|c|}{ Aragonite } & \multicolumn{3}{|l|}{ Vaterite } \\
\hline & & L.M & $v_{4}$ & $v_{1}$ & L.M & $v_{4}$ & $v_{1}$ & L.M & $v_{4}$ & $v_{1}$ \\
\hline \multicolumn{2}{|c|}{$\begin{array}{l}\text { Wehrmeister } \\
\text { et al., } 2010\end{array}$} & $\begin{array}{l}155 \\
281\end{array}$ & 712 & 1086 & $\begin{array}{l}143,153 \\
163,180 \\
191,206 \\
214,248 \\
262,273 \\
284\end{array}$ & $\begin{array}{l}701 \\
706 \\
717\end{array}$ & 1085 & $\begin{array}{l}105,119 \\
152,177 \\
207,263 \\
301,325\end{array}$ & $\begin{array}{l}668,673 \\
685,738 \\
743,751\end{array}$ & $\begin{array}{l}1075 \\
1079 \\
1090\end{array}$ \\
\hline \multicolumn{2}{|c|}{$\begin{array}{l}\text { Carteret et al., } \\
2009\end{array}$} & $\begin{array}{l}155 \\
281\end{array}$ & 712 & 1086 & $\begin{array}{l}111,116 \\
140,152 \\
178,190 \\
205,215 \\
248,260 \\
272,284\end{array}$ & $\begin{array}{l}697 \\
702 \\
706 \\
716 \\
\end{array}$ & 1085 & $\begin{array}{l}105,118 \\
148,174 \\
207,266 \\
301,332\end{array}$ & $\begin{array}{l}668,683 \\
740,750\end{array}$ & $\begin{array}{l}1075 \\
1090\end{array}$ \\
\hline \multicolumn{2}{|c|}{$\begin{array}{l}\text { Gauldie et al., } \\
1997\end{array}$} & & & & $\begin{array}{l}113,142 \\
153,190 \\
206,242 \\
261,284\end{array}$ & $\begin{array}{l}701 \\
705\end{array}$ & 1085 & n.d. & 713,752 & $\begin{array}{l}1066 \\
1093\end{array}$ \\
\hline \multicolumn{2}{|c|}{$\begin{array}{l}\text { Bischoff et al., } \\
1985\end{array}$} & $\begin{array}{l}154 \\
281\end{array}$ & 711 & 1085 & & & & & & \\
\hline \multirow{2}{*}{$\begin{array}{l}\text { This } \\
\text { study }\end{array}$} & $10^{\circ} \mathrm{C}$ & $\begin{array}{l}146 \\
277\end{array}$ & 709 & 1081 & & & & & & \\
\hline & $20^{\circ} \mathrm{C}$ & $\begin{array}{l}148 \\
275\end{array}$ & 706 & 1081 & & & & $\begin{array}{l}148,170 \\
190,200 \\
210,274 \\
328\end{array}$ & $\begin{array}{l}664,735 \\
745\end{array}$ & $\begin{array}{l}1072 \\
1086\end{array}$ \\
\hline
\end{tabular}

* n.d. = not determined 


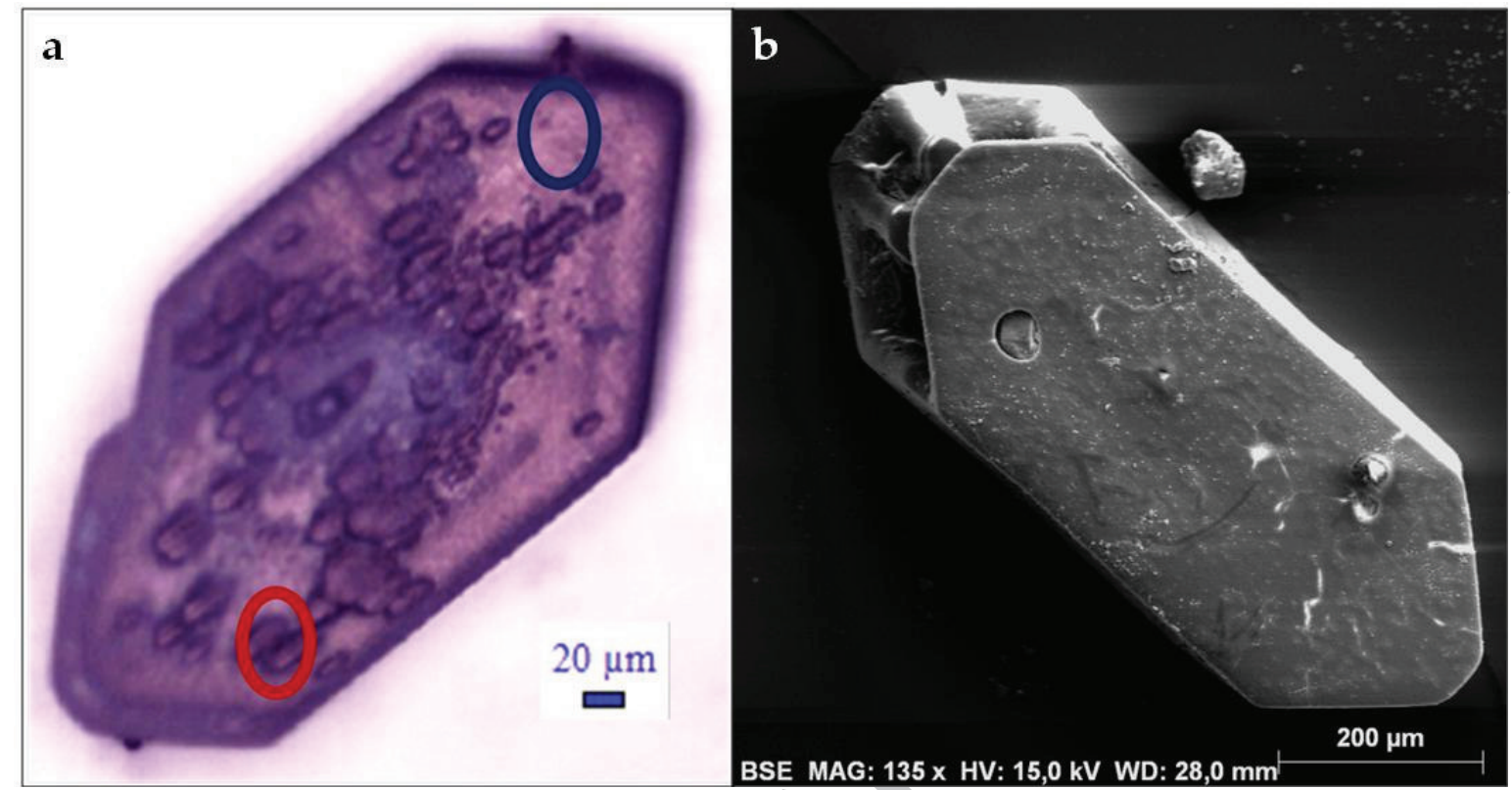

Figure 1 


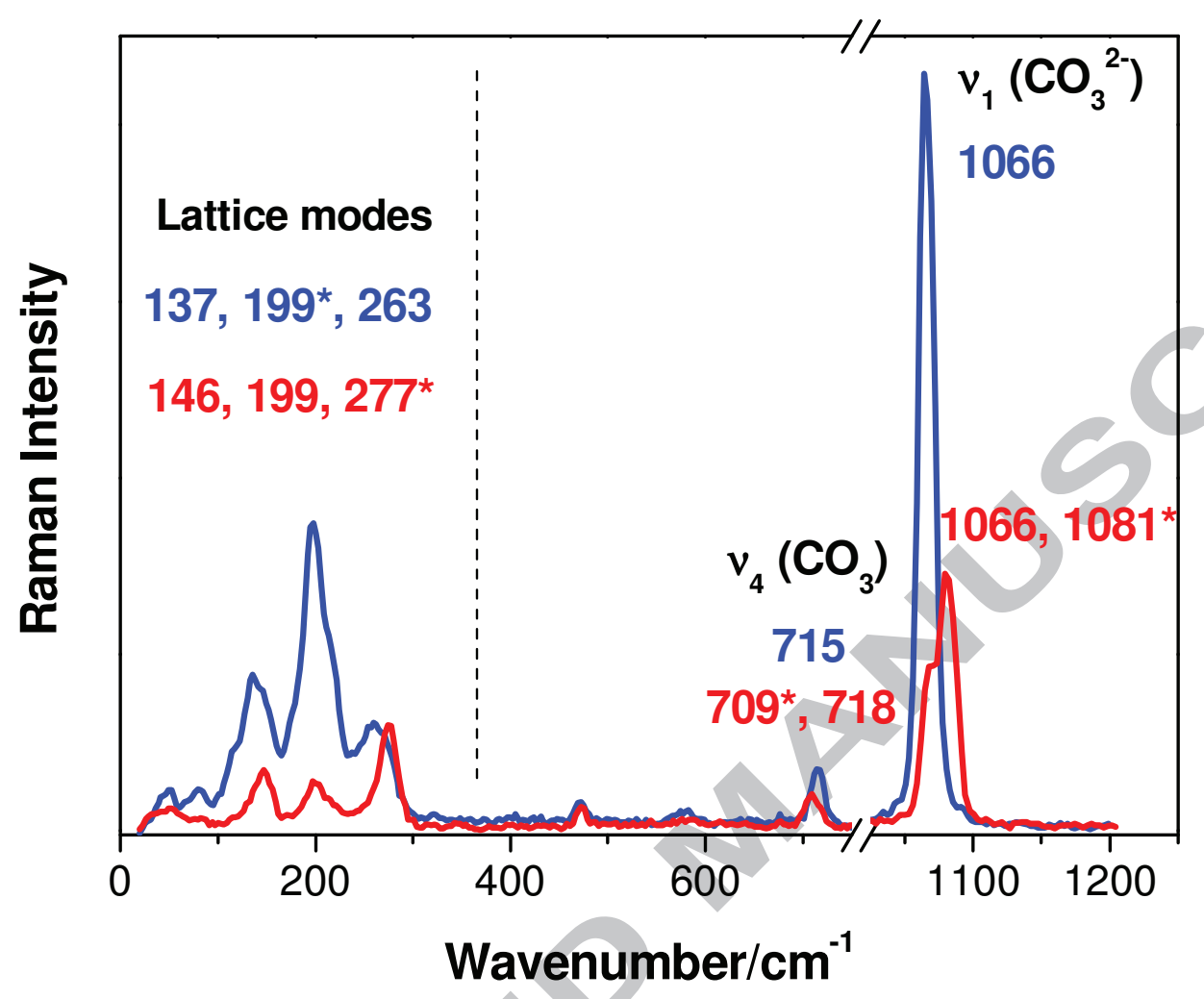

Figure 2 


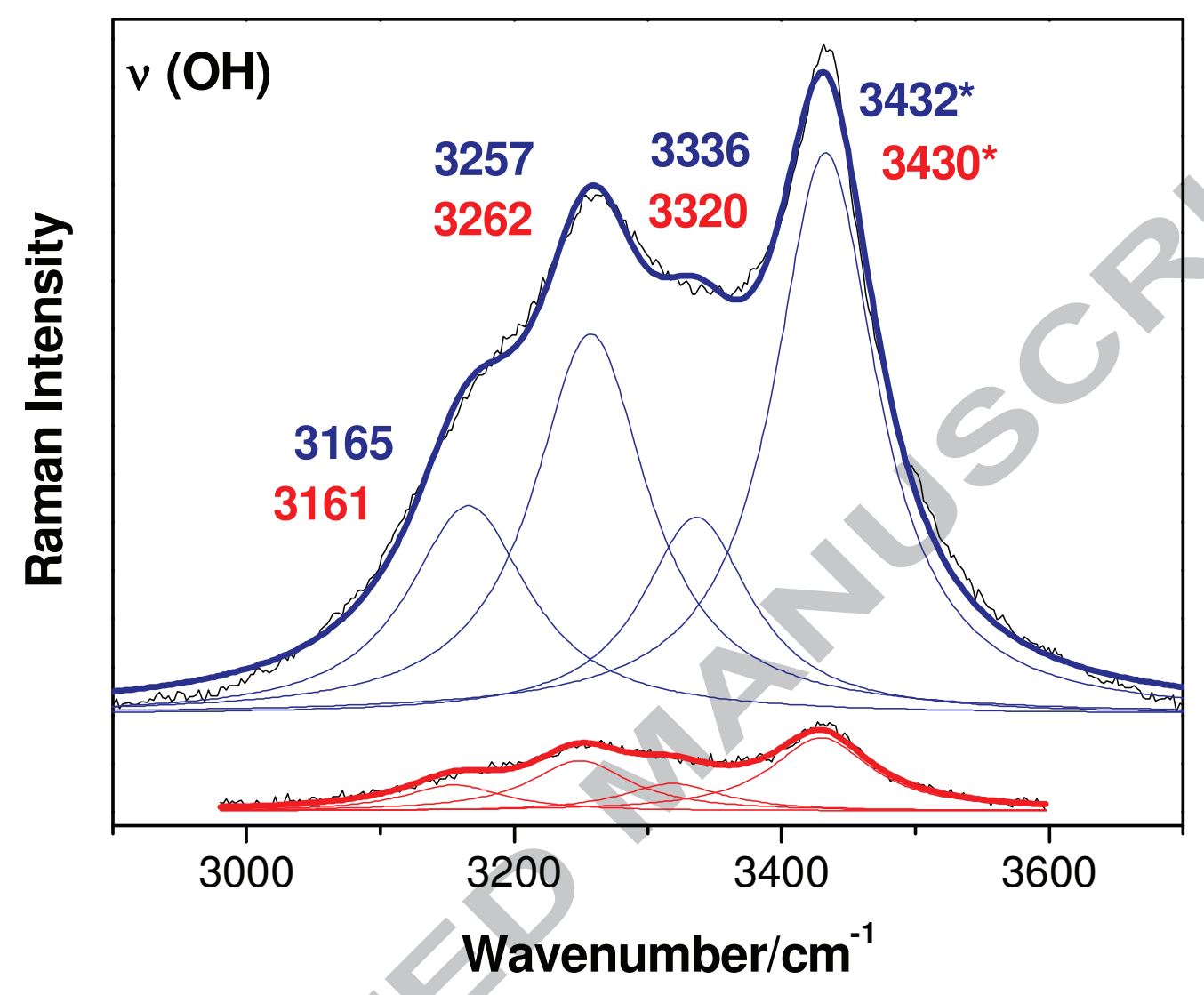

Figure 3 


\section{ACCEPTED MANUSCRIPT}

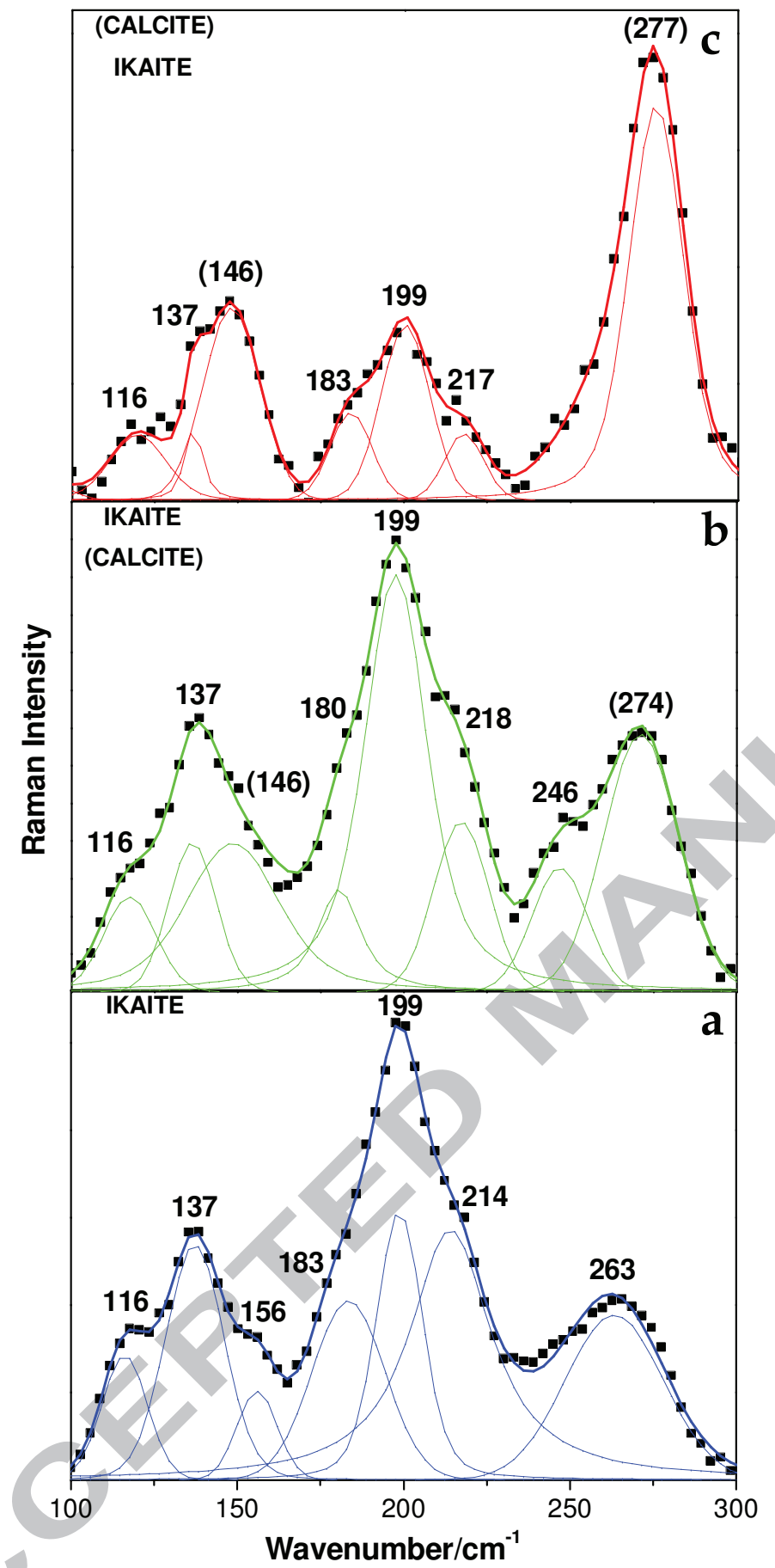

Figure 4 


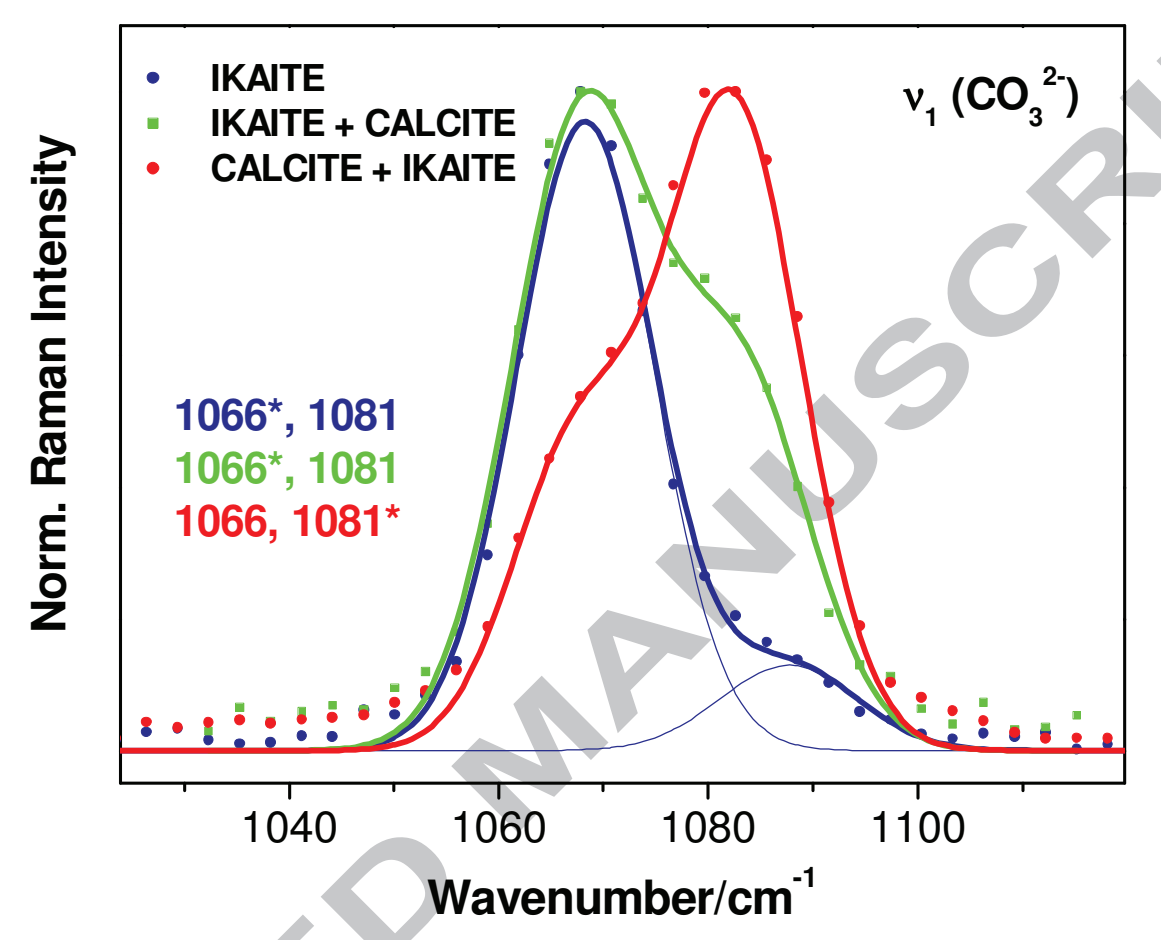

Figure 5 


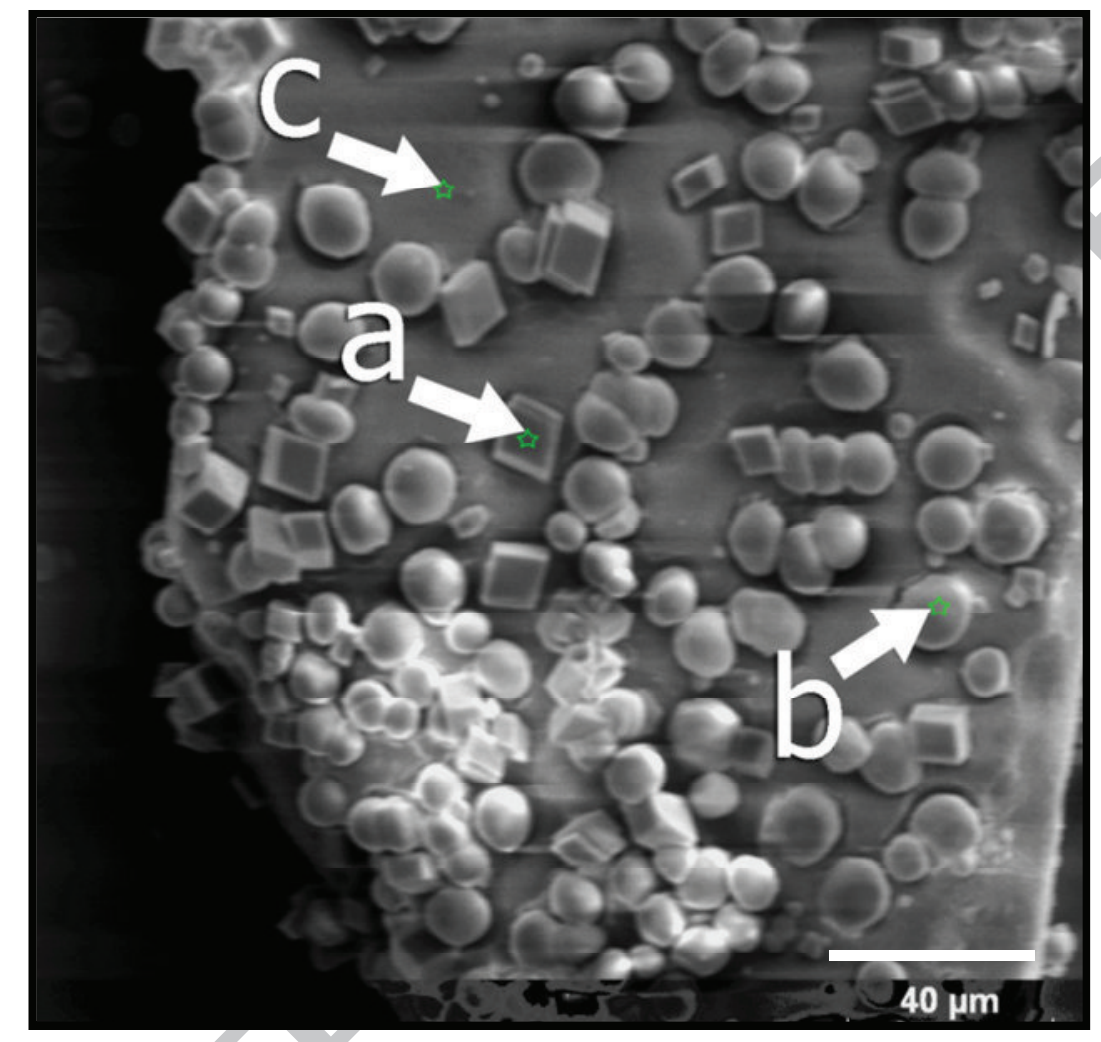

Figure 6 


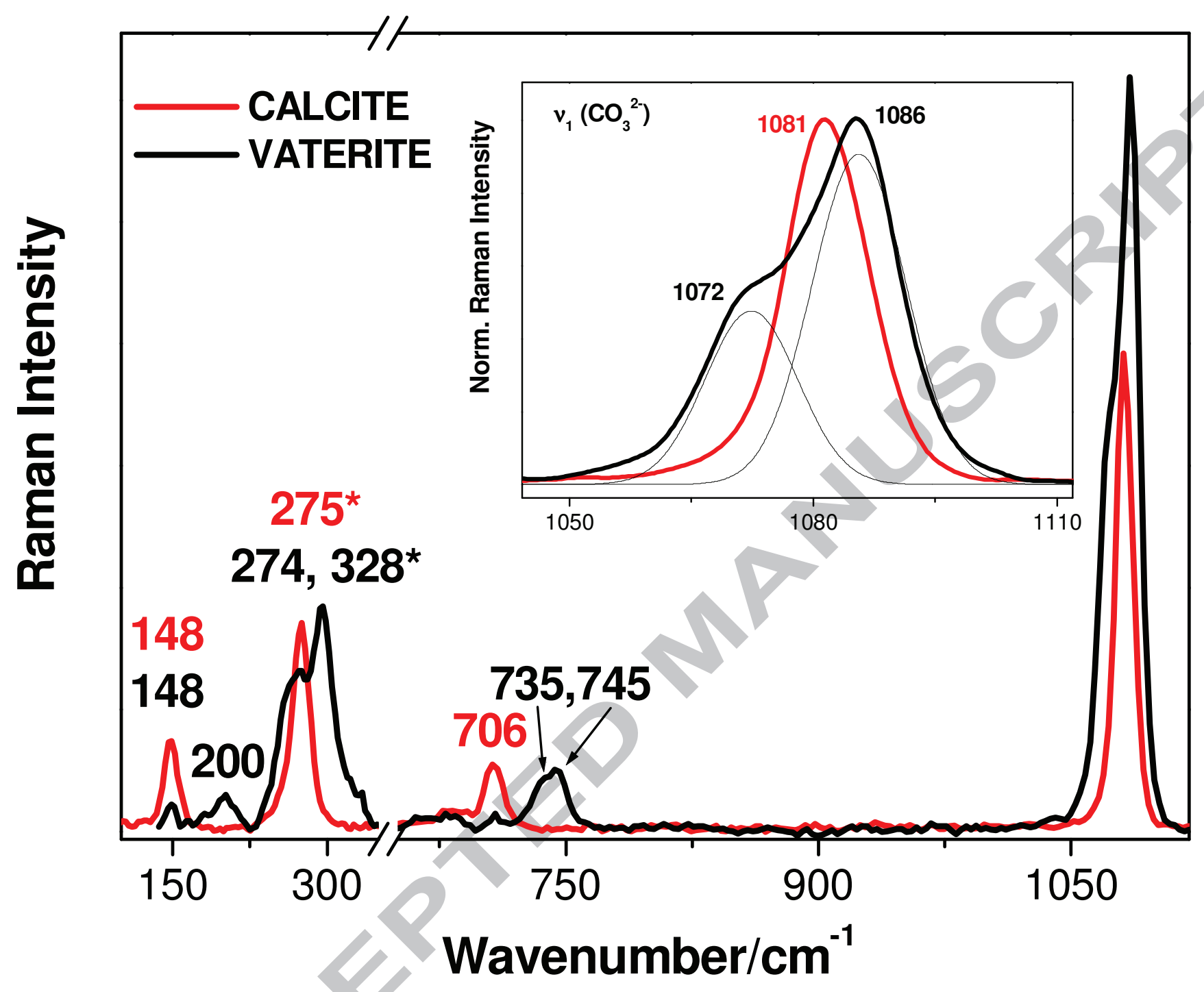

Figure 7 


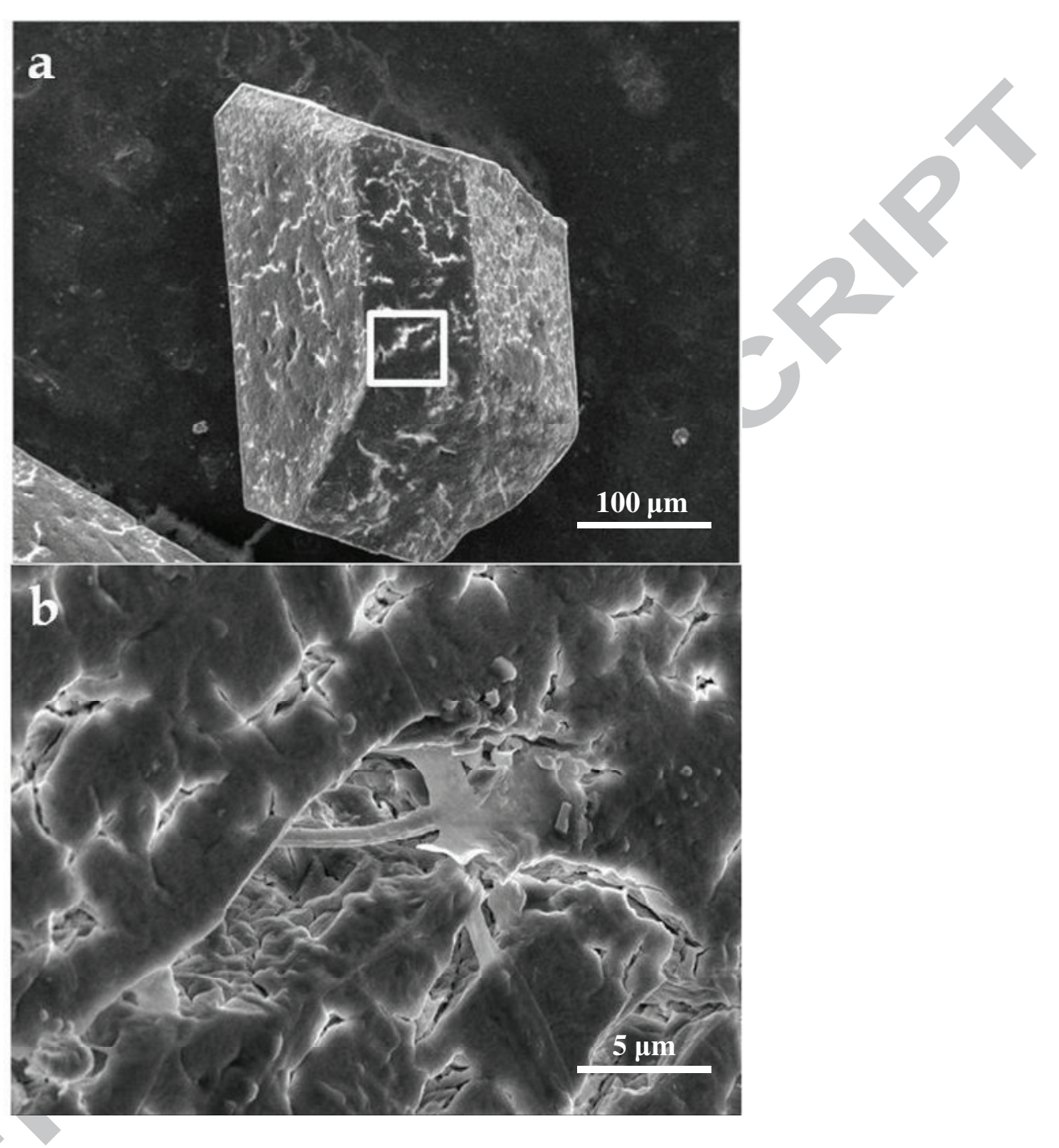

Figure 8 


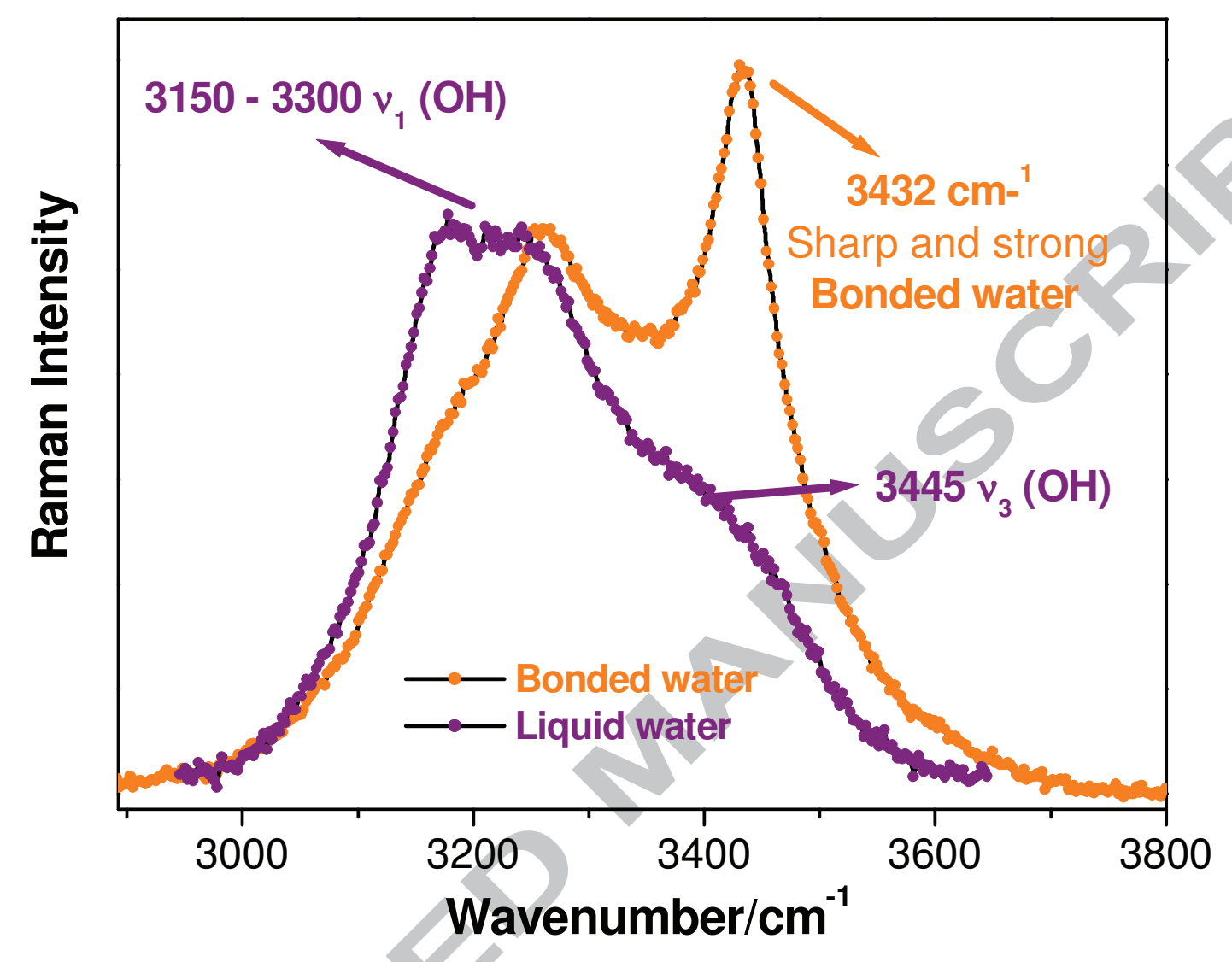

Figure 9 


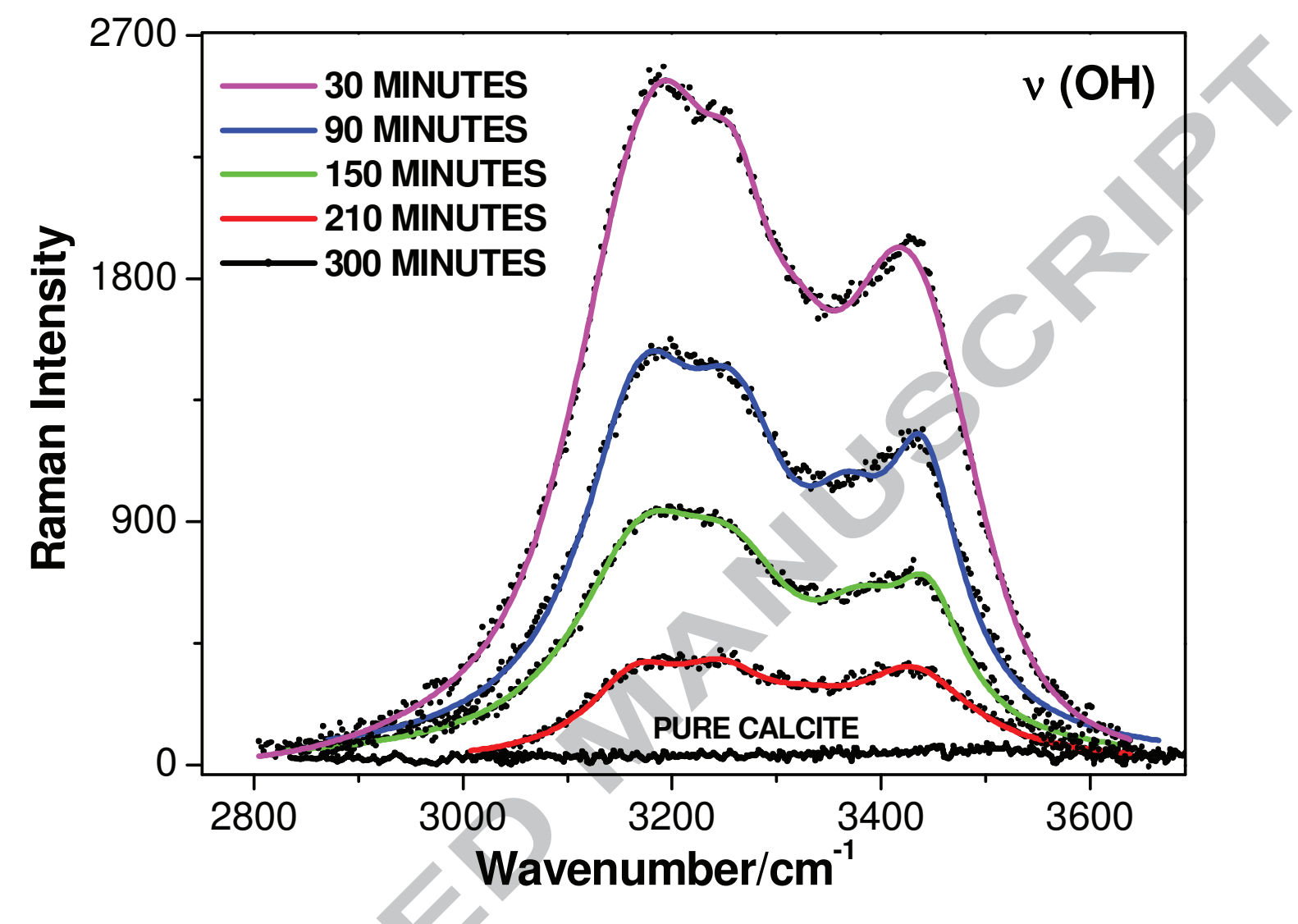

Figure 10 